\title{
PENGGUNAAN TEPUNG DAUN INDIGOFERA SP DALAM PAKAN TERHADAP PENAMPILAN PRODUKSI, KUALITAS TELUR DAN LEMAK DARAH AYAM PETELUR
}

\author{
Alfian Adi Atma11, Dyanovita Al Kurnia2 ${ }^{1 *}$ \\ ${ }^{1}$ Program Studi Peternakan, Fakultas Peternakan, Universitas Islam Lamongan. \\ *Corresponding E-mail: dyanovita@unisla.ac.id
}

\begin{abstract}
ABSTRAK
Indigofera sp adalah jenis tanaman leguminosa dengan genus Indigofera. Penelitian ini bertujuan untuk mengevaluasi pengaruh penggunaan tepung daun indigofera sp terhadap penampilan produksi dan lemak darah ayam petelur. Medote yang digunakan adalah percobaan dengan model RAL (rancangan acak lengkap) 4 perlakuan dan 5 ulangan dengan proporsi P1 kontrol, P2 pemberian tepung daun Indigofera sp 2,5\%, P3 pemberian tepung daun Indigofera sp $5 \%$, dan P4 pemberian tepung daun Indigofera sp 7,5\%. Bahan yang digunakan pada penelitian adalah tepung daun Indigofera sp. Hasil penelitian berdasarkan analisis Ragam menunjukkan bahwa pengaruh perlakuan terhadap konsumsi pakan ayam petelur berbeda nyata $(P<0,05)$, konsumsi pakan tertinggi $\left(86,65 \pm 0,30^{b}\right.$ g/ekor ) pada $P 4$ dengan penambahan tepung daun Indigofera sp 7,5\% memberikan hasil terbaik karena peningkatan konsumsi pakan memberikan pengaruh terhadap produksi telur. HDP ( Hen Day Production ), Egg Mass, konversi pakan, IOFC, kualitas telur terhadap tebal kerabang, skor kuning telur, dan kolesterol kuning telur serta lemak darah meliputi kolesterol total darah, $H D L, L D L$, dan trigliserida menunjukkan pengaruh tidak berbeda nyata $(P>0,05)$.
\end{abstract}

Kata kunci : penampilan produksi; kualitas telur; dan lemak darah.

\section{USE OF INDIGOFERA SP LEAF FLOUR IN FEED AGAINST THE APPEARANCE OF PRODUCTION, QUALITY OF EGGS AND BLOOD FAT OF LAYING HENS}

\begin{abstract}
Indigofera $s p$ is a type of leguminous plant with the genus Indigofera. This study aims to evaluate the effect of the use of indigofera sp flour on the production performance and blood fats of laying hens. Medote used was experiment with RAL model (complete randomized design) 4 treatments and 5 replications with proportion of P1 control, P2 powder of Indigofera sp 2.5\%, P3 of Indigofera sp 5\% leaf powder, and P4 of Indigofera sp 7.5\%. The materials used in this research are Indigofera sp. The result of the research based on the analysis of the Variety showed that the effect of treatment on feeding of laying hens was significantly different $(P<0.05)$, the highest feed intake $(86.65 \pm 0.30 \mathrm{~b} \mathrm{~g} / \mathrm{head})$ in $P 4$ with the addition of Indigofera sp 7,5\% gives the best results because the increase in feed consumption has an effect on egg production. HDP (Hen Day Production), Egg Mass, feed conversion, IOFC, egg quality against shell thickness, egg yolk score and yolk cholesterol and blood lipids include total cholesterol of blood, $H D L, L D L$, and triglyceride showed no significant effect $(P>0.05)$.
\end{abstract}

Key words: production appearance; egg quality; and blood fats.

\section{PENDAHULUAN}

Salah satu tumbuhan yang memiliki kandungan nutrisi yang tinggi dan juga tidak bersaing dengan kebutuhan manusia yaitu legum Indigofera sp, dimana tanaman ini bisa tumbuh pada tanah yang kering, ketersediaan air terbatas serta tahan terhadap genangan air sehingga tanaman ini mudah dalam perawatan. Hassen et al, (2007) menyatakan legum Indigofera sp mempunyai kandungan protein tinggi, serta toleran saat musim kering, dan genangan air. Sehingga diasumsikan dapat menggantikan komposisi subtrat yang lain, yakni dedak sehingga kandungan NDF, ADF dan ADL menurun dan kandungan hemiselulosa dan selulosa dapat meningkat, salah satu alternatif pemanfaatan Indigofera sp dengan menggiling 
menjadi tepung sebagai imbuan pakan alternative. Penggunaan Indigofera sp harus dalam batasan tertentu hal ini disebabkan karena Indigofera sp mempunyai serat kasar yang tinggi bila dikonsumsi oleh ternak jenis non-ruminansia sangat berbahaya bahkan bisa menyebabkan kematian.

Tanaman Indigofera sp memiliki produktivitas yang tinggi dan kandungan nutrien yang cukup baik, terutama kandungan proteinnya yang tinggi. kandungan nutrisi tepung daun Indigofera sp yaitu memiliki bahan kering 89,47\%, energi $3788 \mathrm{kkal} / \mathrm{Kg}$, serat kasar $15,13 \%$, protein kasar $22,30 \%-31,10 \%$. Indigofera sp juga dapat dimanfaatkan sebagai Konsentrat Hijau yang berasal dari hijauan tunggal dari satu spesies tanaman pakan atau beberapa campuran hijauan pakan yang berasal dari spesies tanaman pakan yang berbeda sehingga memenuhi persyaratan sebagai konsentrat hijau. Sebagian besar bahan baku Konsentrat Hijau berasal dari tanaman pakan legum. Salah satu keunggulan dari Konsentrat Hijau selain padat nutrisi juga memiliki fungsi herbal atau jamu bagi ternak karena mengandung klorofil dan senyawa sekunder yang bermanfaat bagi temak. Tarigan et al. (2010) menyatakan bahwa produksi bahan kering tanaman Indigofera sp yang dipotong pada umur 60 hari dengan tinggi potongan $1,0 \mathrm{~m}$ adalah sebesar 31,2 ton/ha/tahun, yang merupakan produksi yang paling tinggi jika dibandingkan dengan umur pemotongan yang lebih tua atau yang lebih muda. Kemudian pada umur pemotongan 60 hari dihasilkan kandungan protein kasar yang lebih tinggi tinggi jika dibandingkan dengan umur pemotongan 90 hari atau 30 hari.

Tepung daun Indigofera sp memiliki produktivitas tinggi, serta kandungan proteinnya tinggi. Berdasarkan uraian tersebut maka dilakukan penelitian tentang penambahan bahan pakan berupa tepung daun Indigofera sp yang tujuannya untuk mempengaruhi penampilan produksi, kualitas telur, dan lemak darah pada ayam petelur.

\section{MATERI DAN METODE \\ Materi}

Materi Ternak

Penelitian dilakukan di Desa Bangilan Kec, Kapas Kab, Bojonegoro. Penelitian ini dilaksanakan pada 1 Desember 2017 - 30 April 2018 dengan menggunakan ternak ayam petelur stain loghman dengan umur 26-31 minggu dan penelitian dilakukan selama 2 bulan.

\section{Bahan Pakan Indigofera sp}

Bahan pakan Indigofera sp diperoleh dari Balai Besar Insemminasi Buatan (BBIB) yang berada di Singosari Malang.

\section{Prosedur Pembuatan Tepung Daun Indigofera sp.}

Bahan yang digunakan pada penelitian adalah daun Indigofera sp yang dipanen pada umur 60 hari. Proses pembuatan tepung daun Indigofera sp. diawali dengan pemanenan tanaman Indigofera sp yang mempunyai umur defoliasi 60 hari, dengan cara memotong bagian pucuk yang berdiameter $<0,5 \mathrm{~cm}$. Kemudian dilanjutkan dengan penjemuran daun Indigofera $\mathrm{sp}$ di rumah kaca sampai kering agar tidak menyebabkan perubahan warna hijau. Selanjutnya digiling sampai menjadi tepung, dan siap untuk digunakan dalam penyusunan pakan.

Prosedur Pengamatan Terhadap Penampilan Produksi, Kualitas Telur, Dan Lemak Darah.

Penambahan pakan berupa tepung daun Indigofera sp yang berpengaruh terhadap penampilan produksi selama penelitian dilakukan penimbangan pakan yang diberikan dan sisa pakan yang diberikan. Pengamatan kualitas telur ayam, selanjutnya dilakukan pengukuran berat telur, berat kerabang telur, dan warna kuning telur. Telur yang diproduksi ditimbang setiap hari dan tiap butirnya, kemudian dirata-ratakan. Setelah penimbangan telur, diambil 2 butir telur setiap ulangan sebagai sampel. Setiap minggu, selama 6 minggu telur diambil kemudian dibuat sampel pada dua hari berturut-turut, setiap ulangan pada perlakuan diambil 2 butir telur untuk sampel. Warna kuning telur dari sampel telur dibandingkan dengan warna Egg Roche Yolk 
Colour Fan. Pengamatan terhadap lemak darah ayam petelur dilakukan pengambilan darah pada hari terakhir penelitian.

\section{Metode}

Metode penelitian eksperimental dengan penggunaan tepung daun Indigofera sp (TDI) untuk ayam petelur. Penambahan tepung daun Indigofera sp sebagian sumber proteinnya dalam pakan ayam petelur. Penelitian ini menggunakan rancangan acak lengkap (RAL) empat perlakuan dan lima ulangan. Taraf berbeda nyata ditentukan dengan One-way analisis of variance (ANOVA) perbedaan dianggap signifikan pada $(\mathrm{P}<0.05)$, jika berbeda nyata dilanjutkan dengan Uji Jarak Duncan (Mattjik dan Sumertajaya, 2006).

Penelitian ini menggunakan Rancangan Acak Lengkap (RAL) yang terdiri dari 4 (empat) perlakuan dan 5 (lima) ulangan dengan pakan yang mengandung proporsii TDI, yaitu:

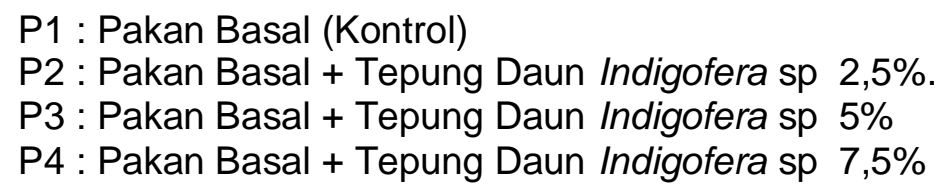

Tabel 1. Komposisi dan Kadungan Nutrisi Pakan Selama Penelitian

\begin{tabular}{lcccc}
\hline \multicolumn{1}{c}{ BAHAN PAKAN } & P0 & P1 & P2 & P3 \\
\hline Jagung & 48 & 48 & 50 & 51 \\
Bekatul & 8 & 6 & 4 & 2 \\
Konsentrat & 35 & 35 & 33 & 33 \\
Dicalcium Phosphat & 4,5 & 4 & 3,5 & 3 \\
Kapur & 4,5 & 4,5 & 4,5 & 3,5 \\
Tepung Daun Indigofera sp & 0 & 2,5 & 5 & 7,5 \\
Total & 100 & 100 & 100 & 100 \\
\hline Kandungan Nutrisi Pakan & & & & \\
\hline BK \% & 89,01 & 88,26 & 88,43 & 87,72 \\
PK \% & 16,26 & 16,22 & 16,51 & 16,72 \\
LK \% & 4,48 & 4,36 & 4,16 & 3,92 \\
SK \% & 3,40 & 3,66 & 3,96 & 4,25 \\
EM (kkal/kg) & 2.721 & 2.699 & 2.704 & 2.711 \\
Ca \% & 3,75 & 3,50 & 3,51 & 3,51 \\
P \% & 0,15 & 0,16 & 0,16 & 0,16
\end{tabular}

\section{HASIL DAN PEMBAHASAN}

Hasil penelitian pada ayam petelur dengan penambahan pakan tepung daun Indigofera $\mathrm{sp}$ jenis legiuminosa terhadap penampilan produksi yang ditampilkan pada tabel 2.

\section{Konsumsi Pakan}

Data penelitian pada perlakuan terhadap konsumsi pakan ayam petelur berbeda nyata, konsumsi pakan tertinggi menunjukan pada perlakuan P4 menunjukkan $\left(86,65 \pm 0,30^{\mathrm{b}} \mathrm{g} / \mathrm{ekor}\right)$ dengan penambahan tepung daun Indigofera sp 7,5\% konsumsi pakan memperoleh nilai yang 
baik, kemudian perlakuan P3 penambahan tepung daun Indigofera sp 5\% dengan nilai rata rata sebanyak $\left(85,91 \pm 0,22^{\mathrm{a}}\right.$ g/ekor), P2 penambahan tepung daun Indigofera sp $2,5 \%$ dengan nilai rata - rata sebanyak $\left(85,92 \pm 0,46^{\mathrm{a}} \mathrm{g} / \mathrm{ekor}\right)$, $\mathrm{P} 1$ penambahan tepung daun Indigofera $\mathrm{sp} 0 \%$ dengan nilai rata - rata sebanyak $\left(85,78 \pm 0,08^{\mathrm{a}} \mathrm{g} / \mathrm{ekor}\right)$.

Tabel 2. Pengaruh Pemberian Tepung Daun Indigofera sp Terhadap Penampilan Produksi Ayam Petelur

\begin{tabular}{|c|c|c|c|c|}
\hline \multirow[b]{2}{*}{ Variabel } & \multicolumn{4}{|c|}{ Perlakuan } \\
\hline & P1 & $\mathbf{P 2}$ & P3 & $\mathbf{P 4}$ \\
\hline $\begin{array}{l}\text { Konsumsi pakan } \\
\text { (g/ekor/hri) }\end{array}$ & $85,78 \pm 0,08^{a}$ & $85,92 \pm 0,46^{a}$ & $85,91 \pm 0,22^{a}$ & $86,65 \pm 0,30^{b}$ \\
\hline HDP (\%) & $91,59 \pm 4,85$ & $85 \pm 5,88$ & $81,51 \pm 9,82$ & $91.03 \pm 3,05$ \\
\hline Egg mass (g/ekor/hari ) & $48,56 \pm 1,29$ & $50,19 \pm 2,37$ & $50,46 \pm 1,51$ & $49,33 \pm 1,25$ \\
\hline Konversi pakan & $1,77 \pm 0,05$ & $1,71 \pm 0,08$ & $1,70 \pm 0,05$ & $1,76 \pm 0,04$ \\
\hline IOFC (Rp) & $359,3 \pm 24,42$ & $336,4 \pm 46,58$ & $392,8 \pm 31,27$ & $368,2 \pm 24,65$ \\
\hline
\end{tabular}

Keterangan : Notasi yang berbeda nyata pada baris yang sama menunjukkan perbedaan yang berbeda nyata $(P<0,05)$.

Berdasarkan hasil analisis ragam menunjukkan bahwa penggunaan tepung daun Indigofera sp memberikan pengaruh berbeda nyata $(\mathrm{P}<0,05)$ terhadap konsumsi Pakan. Perbedaan yang nyata ditunjukkan pada perlakuan $P 4$ yaitu $86,65 \pm 0,30^{b}$ hal ini mungkin disebabkan oleh kandungan protein kasar yang lebih tinggi dibandingkan dengan perlakuan yang lainnya. Keadaan ini mengindikasikan bahwa pakan yang mengandung tepung daun Indigofera sp memiliki palatabilitas yang baik. Konsumsi pakan dipengaruhi oleh suhu lingkungan, kualitas dan kuantitas pakan. Menurut surai (2003) yaitu imbangan antara protein dan energi dalam pakan mempengaruhi jumlah konsumsi pakan. ayam mengkonsumsi pakan untuk memenuhi kebutuhan energinya. Jika kebutuhan energi belum terpenuhi ayam akan terus makan. Sebaliknya, bila energi dalam pakan tinggi, maka ayam akan mengurangi konsumsinya.

\section{HDP (Hen Day Production)}

Berdasarkan hasil analisis menunjukkan bahwa Hen Day Production pada penggunaan tepung daun Indigofera sp dalam pakan tidak memberikan pengaruh nyata $(P>0,05)$ terhadap Hen Day Production. Masing-masing perlakuan menunjukkan hasil P4 menunjukkan (91.03 $\pm 3,05 \mathrm{~g} /$ ekor) dengan penambahan tepung daun Indigofera sp 7,5\%, kemudian perlakuan P3 penambahan tepung daun Indigofera sp $5 \%$ dengan nilai rata - rata sebanyak $(81,51 \pm 9,82$ g/ekor), P2 penambahan tepung daun Indigofera sp 2,5\% dengan nilai rata - rata sebanyak (85 $\pm 5,88 \mathrm{~g} / \mathrm{ekor}), \mathrm{P} 1$ penambahan tepung daun Indigofera sp $0 \%$ dengan nilai rata - rata

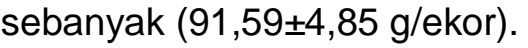

Menurut Gunawan dan Siombing (2004), suhu lingkungan yang tinggi diperlukan lebih banyak pengaturan suhu tubuh, berpeluang mengurangi penyediaan energi untuk memproduksi telur. Penggunaan tepung daun Indigofera sp sampai level 7,5\% mengurangi palatabilitas dalam pakan menyebabkan penurunan konsumsi pakan. Konsumsi pakan akan mempengaruhi produksi telur, jika konsumsi sedikit maka produksi telur akan menurun.

\section{Egg Mass}

Berdasarkan hasil analisis ragam menunjukkan bahwa masing-masing perlakuan menunjukkan tidak berbeda nyata $(P>0,05)$. Data yang disajikan menunjukkan bahwa nilai Egg Mass paling tinggi adalah pada perlakuan 3 (penambahan tepung daun Indigofera sp sebanyak $5 \%$ ) yaitu 50,46\%, sedangkan nilai Egg Mass yang paling rendah adalah pada kontrol yaitu $48,56 \%$. Pemberian tepung daun Indigofera sp pada perlakuan ini tidak berpengaruh terhadap produksi telur harian akan tetapi menghasilkan berat telur yang signifikan, hal ini disebabkan karena tepung daun Indigofera sp memiliki kandungan protein yang cukup tinggi.

Serat kasar yang tinggi dalam ransum sulit dicerna oleh ayam petelur dan akan menurunkan daya cerna dan daya serap zat-zat makanan termasuk protein (Laksmiwati dan Siti, 2012). Menurut Leeson dan Summers (2005) protein dan asam amino (terutama metionin) merupakan zat makanan yang paling berperan dalam mengontrol ukuran telur, disamping 
genetik dan ukuran tubuh unggas. Menurut Piliang dan Soewondo (2006), Ternak yang mengkonsumsi protein dalam konsentrasi yang cukup tinggi akan mempermudah penyerapan kalsium dan berpengaruh terhadap proses pembentukan kerabang telur dan produksi telur. Produksi telur massa merupakan rata-rata berat telur harian sehingga banyak sedikitnya produksi telur/Henday production akan mempengaruhi massa telur.

\section{Konversi Pakan}

Berdasarkan analisis statistik menunjukkan bahwa penggunaan tepung daun Indigofera sp pada pakan ayam ras petelur tidak memberikan pengaruh nyata $(P>0,05)$ terhadap konversi pakan. Penggunaan tepung daun Indigofera sp dalam pakan memiliki perbedaan terhadap konversi pakan yang ditunjukkan terhadap perlakuan P4 yang dibandingkan dengan perlakuan kontrol tanpa tepung daun Indigofera sp. Konversi pakan merupakan salah satu ukuran yang banyak digunakan untuk menyatakan tingkat efisien pemanfaatan pakan oleh ternak yaitu perbandingan antara pakan yang dimakan dalam menghasilkan sejumlah telur. Konversi pakan dihitung setiap minggu dengan cara membandingkan jumlah pakan (g) yang dikonsumsi dengan massa telur setiap minggu.

Pemanfaatan tepung daun Indigofera sp dengan level 7,5\% dalam pakan menyebabkan perbedaan terhadap konversi pakan. Tingginya nilai konversi pakan pada perlakuan P4 yaitu 1,76 menunjukkan bahwa ayam petelur pada pelakuan ini sangat efisien dalam penggunaan pakan untuk kebutuhan produksi dan pembentukan telur. konversi pakan erat kaitannya dengan konsumsi pakan dan produksi telur. Semakin tinggi nilai konversi pakan yang diperoleh, maka semakin efisien ternak. Tinggi rendahnya konversi pakan sangat ditentukan oleh keseimbangan antara energi metabolisme dengan zat-zat nutrisi terutama protein dan asam-asam amino. (Nuriani et al, 2008)

\section{Income Over Feed Cost (IOFC)}

Hasil penelitian pada pemberian tepung daun Indigofera sp terhadap IOFC ayam petelur menunjukkan pengaruh nyata $(\mathrm{P}<0,05)$. Pada perlakuan $\mathrm{P} 1, \mathrm{P} 2, \mathrm{P} 3$ dan $\mathrm{P} 4$. Pemberian tepung daun Indigofera sp dengan taraf $5 \%$ memberikan pengaruh nyata yang dibandingkan dengan pemberian taraf $7,5 \%$. Biaya pakan kontrol lebih rendah dibandingkan dengan pakan perlakuan dan biaya pakan tersebut berbeda sangat nyata satu sama lain, hal ini disebabkan harga pakan tanpa perlakuan $0 \%$ lebih murah dibandingkan dengan pakan perlakuan $2,5 \%$ dan, $7,5 \%$. IOFC sangat dipengaruhi oleh konsumsi pakan, bobot akhir, harga pakan, dan harga jual ayam. Nilai IOFC akan meningkat apabila nilai konversi menurun dan apabila nilai konversi ransum meningkat maka IOFC akan menurun. Rata-rata IOFC ayam betina tipe medium yang dipelihara selama 8 minggu dengan kepadatan kandang 10 ekor/ hari berkisar antara 1,75 sampai 2,19, sedangkan rata-rata IOFC ayam tipe medium dengan kepadatan kandang 10, 12 , 14 dan 16 ekor/hari yang dipelihara selama 7 minggu di kandang postal berkisar antara 1,33 sampai 1,54 (Ardiansyah et al, 2013)

\section{Kualitas Telur}

Hasil penelitian pada ayam petelur dengan imbuhan pakan berupa tepung daun Indigofera sp terhadap kualitas telur dapat dilihat pada tabel 3.

\section{Tebal Kerabang}

Berdasarkan analisis statistik menunjukkan bahwa penggunaan tepung daun Indigofera $\mathrm{sp}$ pada pakan ayam ras petelur tidak memberikan pengaruh nyata $(P>0,05)$ terhadap tebal kerabang. Warna kerabang telur ayam ras dibedakan menjadi dua warna utama, putih dan coklat. Perbedaan warna ini dipengaruhi oleh genetic dari masing masing ayam. Warna coklat pada kerabang dipengaruhi oleh porpirin yang tersusun dari protoporpirin, koproporpirin, uroporpirin, dan beberapa jenis porpirin yang belum teridentifikasi. (Hargitai et al, 2011). 
Tabel 3. Pengaruh Pemberian Tepung Daun Indigofera sp Terhadap Kualitas Telur.

\begin{tabular}{lcccc}
\hline \multirow{2}{*}{ Variabel } & \multicolumn{4}{c}{ Perlakuan } \\
\cline { 2 - 5 } & P1 & P2 & P3 & P4 \\
\hline Tebal Kerabang & $0,51 \pm 0,02$ & $0,51 \pm 0,01$ & $0,49 \pm 0,02$ & $0,50 \pm 0,02$ \\
$\begin{array}{l}\text { Skor Warna Kuning Telur } \\
\begin{array}{l}\text { Kolesterol Kuning Telur } \\
\text { (mg/butir) }\end{array}\end{array}$ & $7,6 \pm 0,55$ & $8,4 \pm 1,34$ & $8,6 \pm 1,14$ & $9 \pm 2,35$ \\
\hline
\end{tabular}

\section{Skor Warna Kuning Telur}

Skor warna kuning telur pada penelitian ini menunjukkan hasil yang tidak berbeda nyata $(P>0,05)$. Hal ini menunjukan bahwa penambahan tepung daun Indigofera sp sampai taraf $7,5 \%$ dalam pakan mampu meningkatkan warna kuning telur, ini terjadi kemungkinan karena kadar serat kasar dalam Indigofera sp mudah terserap oleh ayam. Indigofera sp mengandung serat kasar yang tinggi, yaitu sekitar $25,77 \%$. Pigmen karotenoid mudah diserap oleh kuning telur, karena pigmen alami yang berasal dari tanaman dengan kandungan serat kasar tinggi lebih mudah diserap dan tersedia dalam penyerapan saluran pencernaan dan penimbunannya pada yolk dibandingkan pigmen sintetik yang terbalut gelatin. Warna kuning telur dalam penelitian ini berkisar 9 2,35 adalah sudah mendekati selera konsumen. Kandungan komposisi gizi telur terdiri antara lain : air 73,7\% ; Protein 12,9\% ; Lemak 11,2\% dan Karbohidrat 0,9\%. dan kadar lemak pada putih telur hamper tidak ada. Lemak di dalam telur terdapat pada kuning telur, yaitu mencapai 32\%, sedangkan pada putih telur kandungan lemaknya sangat sedikit. Maka pengamatan lemak dan kolesterol lebih efektif dilakukan pada kuning telur (Yamamoto et al, 2007).

\section{Kolesterol Kuning Telur}

Kadar kolesterol kuning telur dilakukan dengan melakukan analisa di laboratorium pada hari terakhir penelitian. Rataan kolesterol kuning telur hasil penelitian dapat di lihat pada tabel 3. Pemberian tepung daun Indigofera $\mathrm{sp}$ terhadap kelesterol kuning telur tidak memberikan perbedaan yang nyata $(P>0,05)$. Telur yang diproduksi oleh ayam yang diberi pakan campuran tepung daun Indigofera sp mempunyai kandungan kolesterol yang rendah. Tepung daun Indigofera sp merupakan tanaman yang pengolahannya tidak melalui proses fermentasi, oleh karena itu zat-zatnya tidak rusak sehingga dapat mempertahankan berbagai kandungan nutrisi yang terdapat didalamnya, seperti vitamin $D$. Penambahan tepung daun Indigofera sp dalam pakan ayam petelur akan menghasilkan produksi telur yang rendah kolesterol sehingga lebih aman untuk dikonsumsi. Penggunaan tepung daun Indigofera sp dalam pakan dengan jumlah $5 \%$ mampu mempengaruhi kadar kolesterol kuning telur. Hal ini terjadi karena tepung daun Indigofera sp mengandung zat aktif berupa antioksidan yang dapat berperan untuk mengontrol kolesterol pada kuning telur (karena kolesterol telur hampir semuanya berada pada kuning telur) (Santoso et al, 2013).

\section{Lemak Darah}

Hasil pengukuran kadar kolesterol total, HDL, dan LDL, trigliserida, pada ayam petelur disajikan pada Tabel 10. Hasil analisis statistik menunjukkan bahwa pemberian tepung daun Indigofera sp tidak berbeda nyata $(P>0,05)$ dilihat pada tabel 4 . 
Tabel 4. Rata-Rata Kolesterol Total, High Density Lipoprotein (HDL), Low Density Lipoprotein (LDL), Dan Trigliserida, Pada Darah Ayam Petelur

\begin{tabular}{lcccc}
\hline \multirow{2}{*}{ Variabel } & \multicolumn{4}{c}{ Perlakuan } \\
\cline { 2 - 5 } & P1 & P2 & P3 & P4 \\
\hline Kolesterol Total (mg/dl) & $89,6 \pm 14,40$ & $105,2 \pm 26,97$ & $79,2 \pm 16,30$ & $91,8 \pm 2,17$ \\
HDL (mg/dl) & $22 \pm 4,47$ & $26 \pm 6,24$ & $19,6 \pm 3,36$ & $26,2 \pm 16,41$ \\
LDL (mg/dl) & $14,4 \pm 2,88$ & $21,6 \pm 11,08$ & $27,6 \pm 15,40$ & $23 \pm 14,66$ \\
Trigliserida (mg/dl) & $820,8 \pm 102,1$ & $836,4 \pm 86,3$ & $557,4 \pm 249,2$ & $554,8 \pm 311,4$ \\
\hline
\end{tabular}

\section{Kolesterol Total Darah}

Perlakuan pada masing-masing perlakuan P1, P2, P3, dan P4 tidak memberikan perbedaan nyata $(P>0,05)$ terhadap kolesterol darah ayam petelur. Hal ini diduga konsentrasi pemberian tepung daun Indigofera sp dalam pakan masih terlalu rendah, karena belum adanya perubahan pada rasio LDL dan HDL, sehingga belum merubah kadar kolesterol. Pemberian tepung daun Indigofera sp belum optimal dalam meningkatkan penyerapan nutrisi dan memproduksi enzim bile salt hydrolise (BSH) Tabel 3. Kadar kolesterol darah masih dalam kisaran yang normal yaitu 79,2-105,2 mg/dl. Menurut pendapat Basmacioglu dan Ergul (2005), bahwa pemberian tepung daun Indigofera sp belum berfungsi optimal karena terhambatnya penyerapan nutrisi pakan dengan meningkatnya produksi lendir yang dihasilkan sel goblet yang terbentuk dari dinding sel Saccharomyses cerevisiae (S. cerevisiae).

\section{HDL(High Density Lipoprotein)}

Hasil rata-rata HDL darah ayam petelur adalah 19,6-26,2 mg/dl. Hasil analisis statistik menunjukkan pemberian tepung daun Indigofera $\mathrm{sp}$ tidak berbeda nyata $(P>0,05)$ terhadap kadar HDL. Rerata kadar HDL lebih dari kisaran normal, kisaran HDL normal yaitu $>22 \mathrm{mg} / \mathrm{dl}$ (Basmacioglu dan Ergul, 2005). Hasil penelitian yang dilakukan bahwa HDL berkisar 40,5-50,4 $\mathrm{mg} / \mathrm{dl}$. Kadar HDL yang meningkat menunjukkan terdapat respons dari perlakuan yang diberikan. HDL ayam betina berkisar antara 40,5 mg/dl. Molekul HDL relatif kecil dibandingkan lipoprotein lain, sehingga dapat melewati sel endotel vaskular dan masuk ke dalam intima untuk mengangkut kembali kolesterol yang terkumpul dalam makrofag. Selain itu, HDL juga mempunyai sifat anti-oksidan sehingga dapat mencegah terjadinya oksidasi LDL (Hartini dan Okid, 2009).

\section{LDL(Low Density Lipoprotein)}

Hasil penelitian menunjukkan rata-rata perlakuan kadar LDL adalah 21,6-27,6 mg/dl. Pemberian tepung daun Indigofera sp tidak berbeda nyata $(P>0,05)$ terhadap kadar LDL darah ayam petelur. Hal ini menunjukkan pemberian tepung daun Indigofera sp dengan takaran 0 , 2.5 , 5, dan $7.5 \%$ dalam pakan tidak berpengaruh terhadap LDL darah ayam petelur. Pada penelitian ini LDL masih dalam kisaran normal. Kadar LDL normal menurut Basmacioglu dan Ergul (2005) adalah $<130 \mathrm{mg} / \mathrm{dl}$.

\section{Trigliserida}

Rata-rata pada penelitian terhadap perlakuan kadar trigliserida darah ayam petelur berkisar antara 554,8-836,4 mg/dl. Hasil analisis statistik menunjukkan bahwa pemberian tepung daun Indigofera sp tidak berbeda nyata terhadap kadar trigliserida darah ayam petelur $(\mathrm{P}>0,05)$. Pemberian tepung daun Indigofera $\mathrm{sp}$ dalam pakan akan memengaruhi keseimbangan mikroorganisme dalam saluran pencernaan. (Brummer et al, 2010).

Kadar trigliserida darah pada ketiga perlakuan memberikan hasil yang cenderung menurun dan kontrol memberikan hasil yang cenderung nromal. Kisaran normal trigliserida adalah $<150 \mathrm{mg} / \mathrm{dl}$ (Basmacioglu dan Ergul, 2005). Menurut Santoso (2013), bahwa umur ayam mempengaruhi kandungan trigliserida di dalam serum darah. Semakin tinggi umur maka 
kandungan trigliseridanya semakin meningkat. Umur ayam pada saat pengambilan sampel darah pada penelitian ini antara 26-35 minggu sehingga kadar trigliserida pada perlakuan cenderung menurun dan pada kontrol terlihat normal.

\section{KESIMPULAN}

Berdasarkan hasil penelitian tentang tepung daun Indigofera sp mempunyai pengaruh terhadap komsumsi pakan tapi tidak berpengaruh nyata terhadap HDP (Hen Day Production), Egg mass, Konversi pakan, IOFC (Income Over Feed Cost), selain itu kandungan dari tepung daun Indigofera sp yaitu karotenoid juga memiliki pengaruh terhadap warna kuning telur tetapi tidak berpengaruh terhadap kolesterol kuning telur dan lemak darah.

\section{UCAPAN TERIMA KASIH}

Terimakasih kepada peternakan UD. TIGAN yang sudah memberikan izin untuk melakukan penelitian di Kecamatan Kapas Kabupaten Bojonegoro.

\section{DAFTAR PUSTAKA}

Ardiansyah, F., T. Syahrio., dan N. Khaira. (2013). Perbandingan performa dua strain ayam jantan tipe medium yang diberi ransum komersial broiler. J. Ilmiah Peternakan Terpadu $1(1): 158-163$.

Basmacioglu H, Ergul M. (2005). Research on the factor affecting cholesterol content and some other characteristics of eggs in laying hens - the effect of genotype and rearing system. Turk. J. Vet. Anim. Sci, (29), 157-164.

Brummer, A., C.J.V. Rensburg, and C.A. Moran. (2010). Saccharomyses cerevisiae cell wall product: The effects on gut morphology and performance of broiler chickens. J. Anim. Sci. 40(1):14-21.

Golden, J.B.,D.V. Arbona and K.E.Anderson. (2012). Acomparative examination of rearing parameters and layer production performance for brown egg-type pullets grown for either free-range or cage production. J. Appl. Poultry Science 4 (4):187-191.

Gunawan dan D. T. H. Siombing. (2004). Pengaruh suhu lingkungan tinggi terhadap kondisi fisiologis dan produktivitas ayam buras. Wartazoa.14(1): 31-38.

Hargitai, R., R. Mateo, J. Torok. (2011). Shell thickness and pore density in relation to shell colouration female characterstic, and enviroental factors in the collared flycatcher Ficedula albicollis. J. Ornithol. 152(39): 579-588.

Hartini, M dan Okid, P A. (2009). Kadar kolesterol darah ayam petelur hiperkolesterolemik seterlah perlakaun VCO. Bioteknologi 6 (2): 55-62.

Hassen A, Rethman NFG, van Niekerk WA, Tjelele TJ. (2007). Influence of season/year and species on chemical composition and in vitro digestibility of five Indigofera accession. $J$ Animal Feed Science and Technology 136(2-3): 312-322.

Laksmiwati NM, Siti NW. 2012. Pemanfaatan daun kaliandra (Calliandra calothyrsus) sebagai sumber protein pada pakan itik. Majalah IImiah Peternakan .15 (1). ISSN: 0853-8999.

Leeson S, Summers JD. 2005. Commercial Poultry Nutrition. $3^{\text {rd }}$ Ed. Department of Animal and Poultry Science, University of Guelph. University Books, Canada.

Pilliang WG, Soewondo DAH. 2006. Fisiologi nutrisi, Volume 1. Bogor (Indones): IPB Press. 
Nuriani, Sabrina and S.A. Latif. (2008). Nutrition of the Chiken. $3^{\text {rd }}$ ed. M. L. Scott and Associates Publisher Ithaca, New York.

Santoso, A., N. Iriyanti dan S.T. Rahardjo. (2013). Penggunaan pakan fungsional mengandung omega 3, probiotik dan isolate antihistamin n3 terhadap kadar lemak dan kolesterol kuning telur ayam kampung. Universitas Jendral Soedirman, Purwokerto. Jurnal IImiah Peternakan $1(3): 848-855$.

Surai PF. (2003). Natural antioxidants in Avian Nutrition and Reproduction. England (GB): Nottingham Univ Pr.

Tarigan A, Abdullah L, Ginting SP, Permana IG. 2010. Produksi dan komposisi nutrisi serta kecernaan in vitro indigofera sp pada interval dan tinggi pemotongan berbeda. JITV. 15:188-195.

Yamamoto T, Juneja LR, Hatta H, Kim M. (2007). Hen eggs: Basic and applied science. Canada: University of Alberta. 